\title{
The Physico-Chemical and Mineralogical Characterization of Mg-Rich Synthetic Gypsum Produced in a Rare Earth Refining Plant
}

\author{
Fatai Arolu Ayanda (D), Mohd Firdaus Mohd Anuar*(D), Syaharudin Zaibon and Shamshuddin Jusop \\ Department of Land Management, Faculty of Agriculture, Universiti Putra Malaysia (UPM), \\ Serdang 43400, Selangor, Malaysia; talk2fatty01@gmail.com (F.A.A.); syaharudin@upm.edu.my (S.Z.); \\ shamshud@upm.edu.my (S.J.) \\ * Correspondence: m.firdaus@upm.edu.my; Tel.: +60-124-930-852
}

check for updates

Citation: Ayanda, F.A.; Anuar, M.F.M.; Zaibon, S.; Jusop, S. The Physico-Chemical and Mineralogical Characterization of Mg-Rich Synthetic Gypsum Produced in a Rare Earth Refining Plant. Sustainability 2021, 13, 4840. https://doi.org/10.3390/ su13094840

Academic Editor: Franco Ajmone Marsan

Received: 14 December 2020 Accepted: 8 February 2021

Published: 26 April 2021

Publisher's Note: MDPI stays neutral with regard to jurisdictional claims in published maps and institutional affiliations.

Copyright: (c) 2021 by the authors. Licensee MDPI, Basel, Switzerland. This article is an open access article distributed under the terms and conditions of the Creative Commons Attribution (CC BY) license (https:// creativecommons.org/licenses/by/ $4.0 /)$.
Abstract: The physical, chemical and mineralogical characterization of the constituents of magnesiumrich synthetic gypsum produced in a rare earth-refining plant located in Gebeng, Pahang, Malaysia was conducted through elemental chemical analysis, scanning electron microscopy with Energy Dispersive X-ray (EDX)-analyzer, thermal analysis, X-ray fluorescence and X-ray diffraction. The crystalline nature of the by-product was studied using FTIR spectroscopy. Elemental analysis confirmed the presence of $\mathrm{Ca}$ and $\mathrm{Mg}$, which are essential macronutrients required by plants and this $\mathrm{Ca}$ alongside the high pH (9.17) of MRSG may confer on the material a high acid neutralization capacity. From the result, it was observed that the studied by-product is a heterogeneous crystalline material comprising of gypsum $\left(\mathrm{CaSO}_{4} \cdot 2 \mathrm{H}_{2} \mathrm{O}\right)$ and other major components such as calcium (magnesium) compounds (hydroxide, oxide, silicates, and carbonate) and sulfur. These aggregates may contribute to give an acid neutralization capacity to MRSG. The XRD study of MRSG indicated a high content of gypsum (45.4\%), shown by the d-spacing of $7.609 \AA$ (2-theta 11.63) in the diffractogram. The infrared absorption spectra of MRSG indicate close similarities to mined gypsum. The results of the characterization indicated that MRSG has valuable properties that can promote its use in amending soil fertility constraints on nutrient-deficient tropical acid soils.

Keywords: industrial by-product; physico-chemical characterization; FTIR; thermal analysis; X-ray diffraction analysis; X-ray fluorescence; FESEM-EDX; Acid soil amelioration

\section{Introduction}

Rare earth elements (REEs) refer to a group of fifteen elements called lanthanides, which include Lanthanum, Europium, Cerium, Yttrium and Scandium amongst others. These elements form a chemically uniform group with similar physico-chemical properties and commonly found in the same deposit [1,2]. Until the end of the last century, relatively little is known about the importance of REEs to humans, or of their effect on organisms and the environment [3,4]. However, in recent time, this group of metals have seen increased uses and have become a major component of essential products, especially in the field of high technology [5,6]. The last decade saw a considerable rise in the demand for REEs, largely due to specialized uses in modern electronics such as mobile phones, optical, magnetic and catalytic equipment and photovoltaic modules. Rare earth elements serve vital functions in reducing greenhouse emissions, having specialized use in automobiles, wind turbines, converters, chemical action and other technologies [7]. In 2010, about $130,000 \mathrm{t}$ of these elements were mined, a 20-fold increase compared to 1997 [8], meanwhile, the extraction of rare area elements from the mined ore deposits is followed by an extensive processing stage which produces large amount of by-product.

The refining of rare earth to produce various materials that are essential and nonreplaceable in many electronic, optical, magnetic and catalytic applications, produces large 
amounts of byproducts [7] used in automobiles, wind turbines, converters, chemical action and other technologies. The solid byproducts generated during the refining of lanthanide ore containing rare earth imported from Mount Weld, Australia at the Lynas Advanced Material Plant (LAMP), Malaysia are two contrasting materials. After undergoing a series of chemical processes in the plant, there are two main residues from the rare earth industry, each one named following the process from which they are produced, namely Neutralization Underflow Residue (NUF), a synthetic gypsum also called Magnesium-rich synthetic gypsum (MRSG), and Water Leach Purification (WLP), an iron phosphate residue. While the WLP contains low level of radioactive elements, the Neutralization underflow residue, categorized as Scheduled Waste (SW205) by the Department of Environment (DoE) has been stated to be nonradioactive and permitted for use in research.

According to Lynas [7], Neutralization Underflow Residue, known as Magnesiumrich synthetic gypsum (MRSG) has high $\mathrm{pH}$ and contains gypsum and other nutrients needed by plants such as Mg and S. Due to these properties, the MRSG has potential to be used as an alternative to the conventional fertilizers to supply $\mathrm{Ca}, \mathrm{Mg}$ and/or S, soil conditioner and/or liming agent in ameliorating deficiencies resulting from soil acidity condition. Calcium contained in the MRSG will increase the $\mathrm{pH}$ of acidic soils resulting in the formation of aluminum hydroxide or gibbsites. During the past years, some research groups have carried out studies on the new ways of utilizing this magnesium and gypsum containing by-product by investigating its use as low-cost materials capable of substituting the relatively costlier kieserite and Ground Magnesium Lime (GML) for plant nutrition balance on acid soil $[9,10]$.

It is important to obtain information on the structure and chemical properties of this residue to allow a better knowledge of this material to facilitate its recycling, by confirming its inherent properties and establishing or disputing the ability to the material to function in its projected use while also assessing the environmental impact associated with its agricultural use. It has been reported that the addition of some industrial residue may have valuable benefits in agriculture [11]. These benefits may be direct in terms of improvement in soil fertility, pollutant immobilization and carbon sequestration. Indirect benefits may also be derived from alternative use of industrial by-products because the proper management of many of these residues, considered as waste, highlights the environmental sustainability of their use [12-14] by preventing improper disposal of these materials. Thus, understanding the nature of materials is greatly important for their alternative uses.

The objectives of the study are therefore (1) to determine the macro and micro elements obtained in the MRSG; (2) to characterize the MRSG using different spectroscopy techniques to determine the main constituents in the MRSG; (3) to obtain information on the surface topography and mineral compositions of the MRSG; and (4) to determine the thermal stability property of the MRSG using thermogravimetric analysis (TGA).

\section{Materials and Methods}

The magnesium-rich synthetic gypsum used in this research was provided by the Lynas Malaysia Sdn. Bhd. The industrial by-product is produced through cracking and leaching, solvent extraction and finishing process in the refining of rare earth phosphate mineral. Initially, rare earth phosphate mineral is subjected to cracking and leaching with concentrated $\mathrm{H}_{2} \mathrm{SO}_{4}$, followed by cracking at a high temperature $\left(350-450{ }^{\circ} \mathrm{C}\right)$ to convert the rare earth phosphate minerals to rare earth sulphate (Figure 1). At the leaching stage, water is introduced into the rare earth sulphate to remove impurities in the form of iron phosphogypsum [15].

Water from the plant is treated in several stages through the process of acid neutralization to obtain a solid by-product. In the above-mentioned process, extraction liquids are treated with sodium carbonate, neutralized with magnesium oxide and precipitated with sodium carbonate solution or with oxalic acid and filtered, to produce a Neutralization Underflow Residue also known as Mg-rich synthetic gypsum (MRSG). 


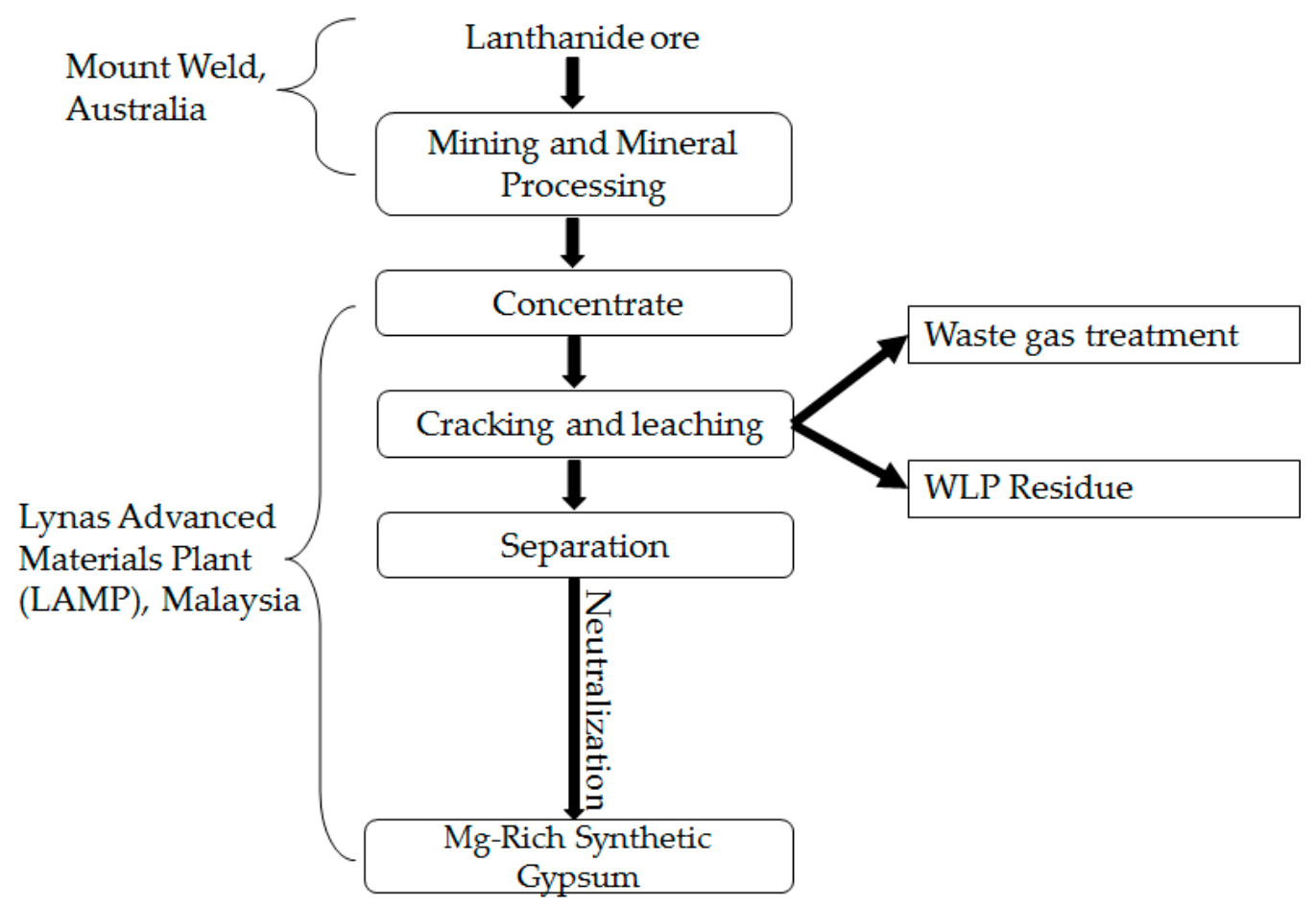

Figure 1. Flow sheet of MRSG production in the process of refining rare earth.

The MRSG samples from different production cycles were labelled with their respective date of production and delivered in batches to the Department of Land Management, Universiti Putra Malaysia (UPM) between 2015-2019. For this study, the homogeneity of MRSG sample was first tested by randomly collecting samples for physiochemical analysis and results show the different samples had equivalent chemical characteristics. The magnesium-rich synthetic gypsum used in this research was provided by the Lynas Malaysia Sdn Bhd. The $\mathrm{pH}$ and electrical conductivity (EC) of the material were measured at a solid/water ratio of 1:2.5 and 1:5 using a pH meter (Model Metrohm 827, Riverview, FL, USA) and electrical conductivity meter (Mettler Toledo SevenEasyTM Conductivity Meter S30, Hamilton, New Zealand), respectively. Total C, N and S in the material were determined using a LECO CR-412 Carbon Analyser (LECO, Corporation, St. Joseph, MO, USA). The analysis of the elemental composition of the material was conducted using the digestion method described in the USEPA3051A [16]. The sample was dissolved in a mixture of nitric acid and perchloric acid at the ratio of 3:1 with the addition of hydrogen peroxide. The content of each element was determined using an inductively coupled plasma-optical emission spectrometer (Optima 8300, Norwalk, CT, ICP-OES Spectrometer by PerkinElmer). The limits of detections (LOD) for the elements were determined using $3 \sigma$ following the method of Boumans [17]. The sensitivity of method used was obtained from the slope of calibration curves. The slopes of the calibration curves of all elements indicate good sensitivity, the coefficients of determination i.e., R2, was 0.999 . The chemical composition of MRSG was determined using X-ray fluorescence (XRF) spectroscopy technique (Philips PW 2404).

The morphology of the MRSG was observed under a Field Emission Scanning Electron Microscope (FESEM) and elements in the material were quantified using Energy Dispersive X-ray (EDX) attached to the FESEM. For this, a known quantity of MRSG samples was weighed on aluminum stub using carbon double-sided tape. The MRSG sample was thinly coated with a film of carbon using a carbon evaporator. Thereafter, the sample was observed under a Scanning Electron Microscope (LEO EVO 40 XVP-Zeiss) equipped with an EDX (Quantax XFlash 5010-Bruker). SEM-EDX observation was carried out using $20 \mathrm{kV}$ accelerating voltage at a working distance of $8.0 \mathrm{~mm}$. The EDX was calibrated using reference standard materials. Upon insertion of the sample into the microscope, selection 
of the mineral grains was performed by moving the microscope stage in a random vertical and lateral manner to avoid bias in grain selection. The chemical compositions of the selected region were determined by EDX on two or more areas of each sample to reduce the margin for error. The mineralogical analysis of the MRSG was conducted by X-ray diffraction analysis using a Philips X'PERT PRO diffractometer (Philips/PANalytical X'Pert Pro-MPD Powder Diffractometer, Eindhoven, Netherlands) in Bragg-Brentano geometry (configuration Theta-2Theta). The diffractometer was operated using $1.54060 \AA \mathrm{CuK} \alpha$ radiation, $\mathrm{Ni} \mathrm{K} \beta$ filters, and a scintillation detector at a voltage of $45 \mathrm{kV}$ and $40 \mathrm{~mA}$ current, acquisition interval $5-80^{\circ}(2 \theta)$ and step size $0.02^{\circ}$ [18]. The software Diffrac.EVA v. 2.1 (Bruker AXS, GmbH, Karlsruhe, Germany) was used in processing the XRD pattern while mineral phases were identified using the ICDD PDF database (ICDD PDF-2 Release 2009).

Fourier transform infrared spectrophotometry (FTIR) spectra of the sample was studied to identify the functional groups on the surface of the material using an FTIR technique. Approximately $2.4 \mathrm{mg}$ of the samples was collected and mixed with $100 \mathrm{mg}$ of $\mathrm{KBr}$ and compressed to make a pellet [19]. The FTIR spectra of the samples were recorded on a Perkin Elmer 1725X FTIR spectrophotometer. The results obtained were deconvolved using Origin Pro 2020. For thermal analysis, the study was conducted using a Mettler SDTA851e with a Mettler TA-4000 TG-50 thermobalance. MRSG sample (40-50 mg) was heated in alumina crucibles under nitrogen atmosphere at $10^{\circ} \mathrm{C} / \mathrm{min}$ from $25^{\circ} \mathrm{C}$ to $1000{ }^{\circ} \mathrm{C}$.

\section{Results and Discussion}

\subsection{Physico-Chemical Characterization}

Magnesium-rich synthetic gypsum is alkaline in nature having a $\mathrm{pH}$ of 9.17 while the EC was $7.12\left(\mathrm{dS} \mathrm{m}^{-1}\right)$, thus its high alkalinity may confer on the material a high acidneutralizing capacity. Therefore, the application of MRSG may have an ameliorative impact on soil acidity [20-22]. Elemental analysis confirmed the presence of elements of $\mathrm{Ca}$ and $\mathrm{Mg}$ which are essential macronutrients required by plants. These elements are the most abundant in the material while some P and $\mathrm{K}$ were also present in the MRSG (Table 1). The contents of $\mathrm{Ca}$ and Mg in the MRSG were almost similar to those of GML used by Shamshuddin and Ismail [23] in their study of an Ultisol in Malaysia. In addition, present in MRSG are trace concentration of elements such as manganese, zinc, copper, selenium, silicon and others (Table 1).

Table 1. Chemical characteristics of the MRSG.

\begin{tabular}{|c|c|}
\hline Properties & Magnesium Rich Synthetic Gypsum \\
\hline $\mathrm{pH} \mathrm{H}_{2} \mathrm{O}$ & 9.2 \\
\hline Electrical Conductivity (EC) $\left(\mathrm{dS} \mathrm{m}^{-1}\right)$ & 7.1 \\
\hline Moisture $(\%)$ & 26.7 \\
\hline $\mathrm{C}(\%)$ & 1.12 \\
\hline $\mathrm{N}(\%)$ & 0.05 \\
\hline $\mathrm{S}(\%)$ & 0.41 \\
\hline $\mathrm{Ca}\left(\mathrm{mg} \mathrm{kg}^{-1}\right)$ & 17,243 \\
\hline $\mathrm{P}\left(\mathrm{mg} \mathrm{kg}^{-1}\right)$ & 234 \\
\hline $\operatorname{Mg}\left(\mathrm{mg} \mathrm{kg}^{-1}\right)$ & 14,396 \\
\hline $\mathrm{K}\left(\mathrm{mg} \mathrm{kg}^{-1}\right)$ & 49 \\
\hline $\mathrm{Na}\left(\mathrm{mg} \mathrm{kg}^{-1}\right)$ & 288 \\
\hline $\mathrm{Fe}\left(\mathrm{mg} \mathrm{kg}^{-1}\right)$ & 1368 \\
\hline $\mathrm{Mn}\left(\mathrm{mg} \mathrm{kg}^{-1}\right)$ & 1175 \\
\hline $\mathrm{Cu}\left(\mathrm{mg} \mathrm{kg}^{-1}\right)$ & 127 \\
\hline $\mathrm{Al}\left(\mathrm{mg} \mathrm{kg}^{-1}\right)$ & 350 \\
\hline $\mathrm{Cd}\left(\mathrm{mg} \mathrm{kg}^{-1}\right)$ & 234 \\
\hline $\mathrm{Zn}\left(\mathrm{mg} \mathrm{kg}^{-1}\right)$ & 38 \\
\hline Loss of ignition (LO1) & 19.39 \\
\hline LODs & $0.05 \mu \mathrm{g} / \mathrm{g}$ \\
\hline
\end{tabular}


Previous studies have reported numerous benefits of the above-listed elements in the cropping system [24,25]. The presence of carbon, nitrogen and sulfur compounds was also confirmed in the material. The MRSG is a by-product, so it was expected that the material contains some heavy metals. This was similar to the result reported by Li et al. [21], where the contents of $\mathrm{Zn}, \mathrm{Cu}$ and As in their studied industrial byproduct were in the range of $40.7,64.9$ and $7.2 \mathrm{mg} \mathrm{kg}^{-1}$, respectively. Heavy metals such as cadmium, copper, nickel, lead, zinc, mercury, and chromium found in industrial by-products are considered potentially toxic elements (PTEs), and through their use, heavy metals enter the soil aside from atmospheric deposition and other anthropogenic sources. Some of these elements are micronutrients for higher plants and deficiency of these micronutrients can impair proper plant function and reduce yield; however, excessive amounts can limit soil productivity by decreasing or altering microbial communities thus, inducing toxicity to plants [26,27].

Several techniques have been identified in order to immobilize heavy metals in soil environment. The risk posed by heavy metals could be reduced with the co-application of organic amendments such as rice husk biochar $(\mathrm{RH})$ and/or empty fruit bunch (EFB). Previous studies show that the sorption of such heavy metals (i.e., $\mathrm{Cd}, \mathrm{Cu}, \mathrm{Zn}, \mathrm{Fe}, \mathrm{As}$ ) has the ability to bind to soil particles, hence reducing the bioavailability of the heavy metals in the soil solution [28-31]. For example, based on Langmuir's adsorption model, the maximum adsorption capacity ( $q_{\max }$ ) of EFB biochar for As was $0.42 \mathrm{mg} \mathrm{g}^{-1}$, which was higher than $\mathrm{RH}$ biochar $\left(0.35 \mathrm{mg} \mathrm{g}^{-1}\right)$ [32]. The same trend was observed for the adsorption maximum, $\mathrm{q}_{\max }$, of $\mathrm{Cd}$ with the values of 15.15 and $3.19 \mathrm{mg} \mathrm{g}^{-1}$, for EFB biochar and RH biochar, respectively. Empty fruit bunch (EFB) biochar had a higher affinity for As than did RH biochar. On the other hand, the binding affinity (b) of $\mathrm{Cd}$ for RH biochar was higher than EFB biochar [32]. The alkaline properties of biochars increased the solution $\mathrm{pH}$, which induced metal immobilization through metal precipitation and decreases metal solubility. At the moment, it is believed that the co-application of MRSG with organic amendments can reduce the risk posed by these heavy metals. The LOI value of MRSG shows presence of concentration of volatile compounds as $\mathrm{CO}_{2}$ and moisture content in the studied material. The result obtained on LOI was similar to that obtained in another gypsum containing industrial by-product [33]; meanwhile, a higher value of LOI was reported in another research on Flue gas desulphurization gypsum containing industrial by-product [34].

The chemical composition of the main constituents of the MRSG were determined using X-ray fluorescence spectroscopy (XRF) and the results of this analysis are presented in Table 2. Elemental chemical analysis and XRF study confirmed the main constituent of the studied MRSG sample as calcium and magnesium. The high amount of calcium and basic oxides is thought to be responsible for the high alkalinity ( $\mathrm{pH}$ 9.17) of the material, giving it a high capacity to neutralize acid media.

Table 2. Result showing XRF spectroscopy of the MRSG.

\begin{tabular}{cc}
\hline Chemical Composition & Amount in \% \\
\hline $\mathrm{CaO}$ & 59.63 \\
$\mathrm{SO}_{3}$ & 29.58 \\
$\mathrm{CeO}_{2}$ & 3.12 \\
$\mathrm{Cl}$ & 2.05 \\
$\mathrm{La}_{2} \mathrm{O}_{3}$ & 2.04 \\
$\mathrm{Fe}_{2} \mathrm{O}$ & 1.62 \\
$\mathrm{MnO}$ & 1.02 \\
$\mathrm{~V}_{2} \mathrm{O}_{5}$ & 0.37 \\
$\mathrm{ZnO}$ & 0.21 \\
$\mathrm{SrO}$ & 0.21 \\
$\mathrm{Y}_{2}$ & 0.07 \\
$\mathrm{ZrO}_{2}$ & 0.04 \\
$\mathrm{CuO}$ & 0.04 \\
\hline
\end{tabular}


There are concerns on the presence of rare earth element such as $\mathrm{La}, \mathrm{Vn}$, and $\mathrm{Sr}$ in the studied material, with study by Li et al. [35] showing that La may affect soil ecosystems at concentrations slightly above natural background levels. Similarly, Larsson et al. [36] conducted a research on the toxicity of vanadium to soil organisms by testing seven levels of vanadate doses of vanadate $\left(3.2-3200 \mathrm{mg} \mathrm{V} \mathrm{kg}^{-1}\right.$ ) on five soils with different characteristics using two microbial and three plant assays to measure toxicity effect of the element. The researcher reported that elevated level of vanadium in the soil can lead to nitrogen inhibition in soils. Liang and Tabatabai [37] observed between $12 \%$ and $62 \%$ inhibition of nitrification in three different soils at vanadium concentrations of $250 \mathrm{mg} \mathrm{kg}^{-1}$ soil. Strontium occurs naturally as an alkaline earth metal; however, various detrimental human health impact has been associated with toxic accumulation of this element through anthropogenic process such as nuclear weapons explosions or wastes from nuclear reactors [38].

\subsection{X-ray Diffraction}

The diffraction patterns of the studied MRGS showed that it was a heterogeneous material comprising a mixture of crystalline phases. The major crystalline component of the solid phase of MRSG is gypsum $\left(\mathrm{CaSO}_{4} \cdot 2 \mathrm{H}_{2} \mathrm{O}-98.66 \%\right)$, shown by the d-spacing of $7.609 \AA$ (2 theta 11.63) in the diffractogram (Figure 2). The high content of $\mathrm{CaSO}_{4} \cdot 2 \mathrm{H}_{2} \mathrm{O}$ results in a high $\mathrm{pH}$ of the material thus giving it a high acid-neutralizing capacity; good in ameliorating acid soils. This is consistent with the previous study by Li et al. [39], where phosphogypsum, an industrial by-product, showed the presence of gypsum which gave the material a high acid-neutralizing property. Calcite $\left(\mathrm{CaCO}_{3}\right)$ was detected in the MRSG, indicated by the d-spacing of $3.036 \AA$ ( 2 theta of 29.41). The presence of Si was identified by the ICP-OES (in solution form), but not by XRD analysis due to its existence in the form of amorphous silica $\left(\mathrm{SiO}_{2}\right)$. This result was comparable with result obtained from the analysis of MRSG conducted by Golder Associates of Australia (courtesy of Lynas) where high amount of gypsum (73-74\%) was reported in the material as well as amount of $\mathrm{Mg}(\mathrm{OH})_{2}$ $(17.1 \%), \mathrm{Ca}(\mathrm{OH})_{2}(4.3 \%)$ and $\mathrm{CaCO}_{3}(2.3 \%)$. The alkaline nature of MRSG was related to its content of $\mathrm{Mg}(\mathrm{OH})_{2}$ and $\mathrm{Ca}(\mathrm{OH})_{2}$.

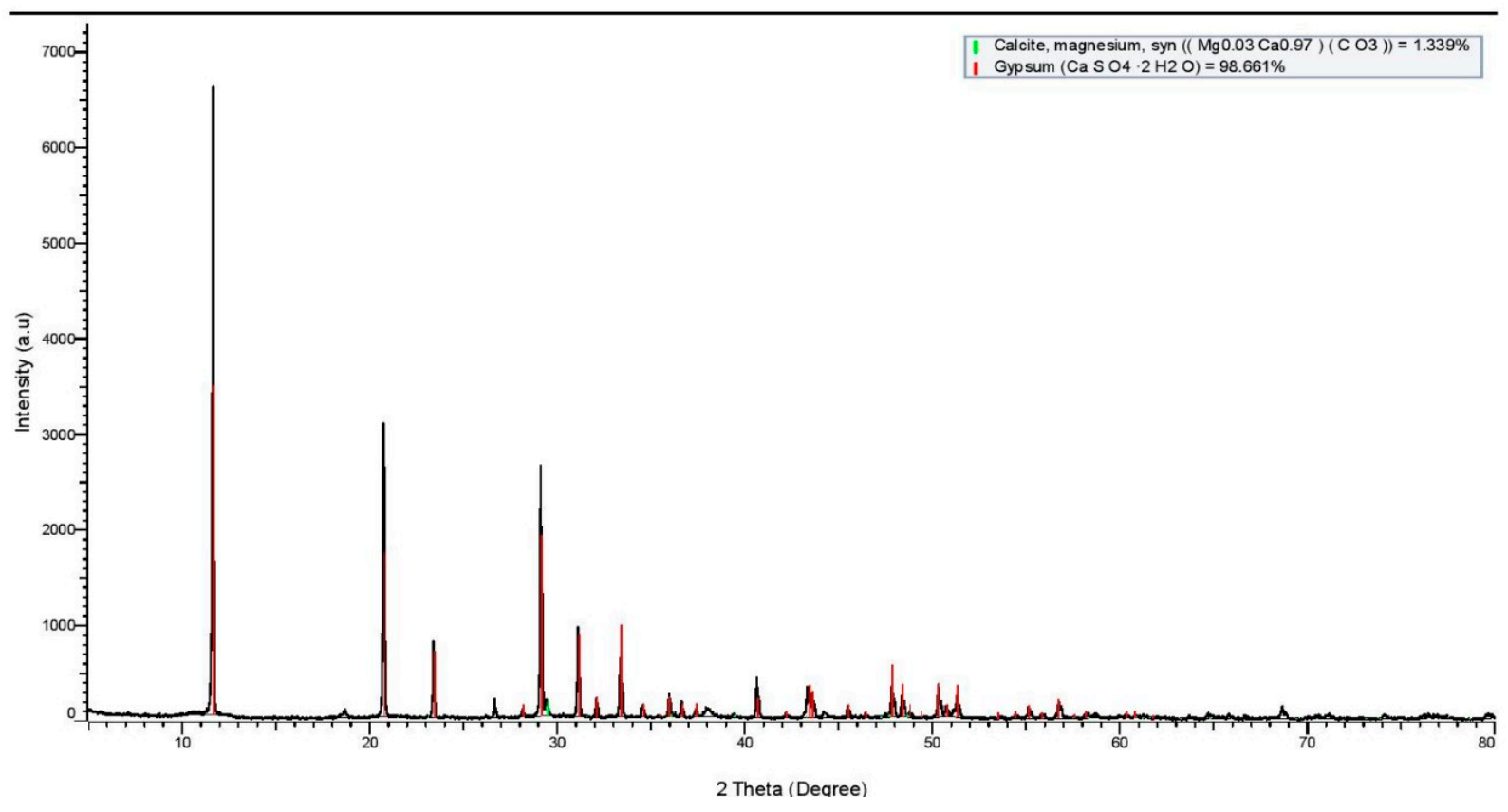

Figure 2. The X-ray diffractogram of MRSG.

\subsection{FTIR Spectroscopy}

Infrared absorption spectra of a crystalline material can provide essential information on the structure, particularly, supplying conclusive evidence on the nature of the func- 
tional groups in the crystal lattice. Spectroscopic assessment of MRSG was conducted to understand the structure of the residue. The FTIR spectra of the sample show similarities to mined gypsum. The intensely strong peak at 3695 corresponds to hydroxyl deformation modes. The strong broadband observed in MRSG at around wavenumbers 3487 and $3369 \mathrm{~cm}^{-1}$ signify that $\mathrm{OH}$ was assigned to the stretching mode of hydroxyl functional group (Figure 3). The bands indicate the presence of hydroxides and oxyhydroxides in MRSG. The presence of hydroxyls in this material can increase the cation exchange capacity of the soil when the material is land applied. Queralt [40] reported that hydrated calcium-magnesium carbonates show a broadband centered around $3435 \mathrm{~cm}^{-1}$ and a sharp band at $3629 \mathrm{~cm}^{-1}$, thus the broad shoulder at $3487 \mathrm{~cm}^{-1}$ could be assigned to both hydroxyl stretching modes of hydrated carbonates and also to adsorbed or coordinated water molecules (Table 3). The band showing at $1440 \mathrm{~cm}^{-1}$ corresponds to C-O stretching modes of the $\mathrm{CO}_{3}{ }^{2-}$ ion [41]. Bands at $1681.00 \mathrm{~cm}^{-1}$ and $1618 \mathrm{~cm}^{-1}$ in MRSG sample could be attributed to the presence of two types of water molecules in gypsum. The absorptions peak at 1099 can denote the Si-O stretching modes of silica and silicates.

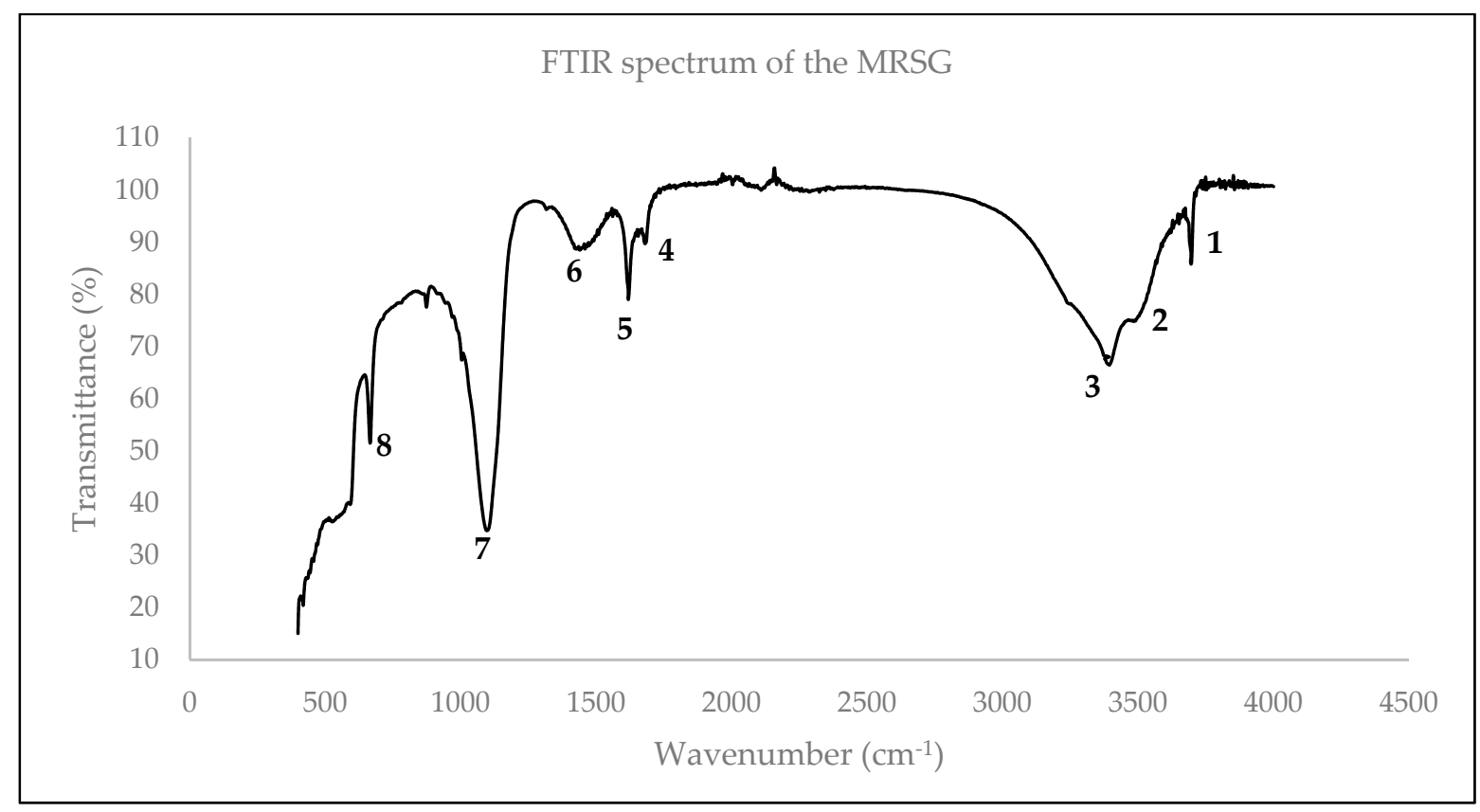

Figure 3. The FTIR spectrum of MRSG.

Table 3. Major bands present in FTIR spectra of the MRSG.

\begin{tabular}{cccc}
\hline No. & Wave No. $\left(\mathbf{c m}^{-\mathbf{1}}\right)$ & Vibration & Functional Groups \\
\hline 1 & 3695 & O-H stretch & Bonded and nonbonded hydroxyl group and water \\
2 & 3487 & O-H stretch & Bonded and nonbonded hydroxyl group and water \\
3 & 3392 & O-H stretch & Bonded and nonbonded hydroxyl group and water \\
4 & 1681 & Stretching & Water molecules \\
5 & 1618 & Stretching & Water molecules \\
6 & 1440 & C-H deformation, $\mathrm{CO}_{2}$ & Alkenes carboxylates and carbonates \\
7 & 1099 & stretch; $\mathrm{C}-\mathrm{O}$ stretch & Silica and silicates; aluminum oxyhydroxide \\
8 & 665 & and irotch o $\mathrm{OH}$ vibration & Sulfates \\
\hline
\end{tabular}

Meanwhile, absorption bands that correspond to hydroxyl vibrations of aluminum oxyhydroxides [42] and iron oxyhydroxides [43] can occur in this region of the spectrum. In addition, intense band at wavenumber $1099 \mathrm{~cm}^{-1}$, in the gypsum containing by-product and deformations at $665.44,594.08$ and $457 \mathrm{~cm}^{-1}$ in MRSG could be attributed to the presence of sulphate functional groups [44]. Similarly, absorption peak in MRSG at 
$875 \mathrm{~cm}^{-1}$ corresponds to carbonate spectrum [44,45]. According to the FTIR spectroscopy, the most abundant components of MRSG are calcium hydroxide, calcium and magnesium carbonates, silicates, and calcium aluminates, which corroborates the XRD results. The aggregates of these compounds may confer a degree of alkalinity (pH 9.17) to MRSG with an accompanying acid neutralization property.

\subsection{Morphology of MRSG}

Identification of the well-crystallized phases in MRSG was conducted using X-ray diffraction, however, SEM can provide information on the microstructure of the industrial by-product, as well as the morphology of the sample. EDX was used in determining the chemical constituents of the mineral phases. The scanning electron micrograph (up to $25,000 \times$ ) of MRSG is shown in Figure 4 . The SEM imaging confirmed the heterogeneity of MRSG as composed of aggregate particles of different nature and sizes. The material was shown to have a rough surface chiefly consisting of particles that are grouped by electrostatic attraction. The micrograph also indicates the presence of wide macropores and interparticle cavities in MRSG. The result shows the occurrence of minor constituent phases similar to those revealed in the FTIR spectroscopy. The abundance of gypsum in the material was confirmed by the presence of the acicular-shaped mineral as shown by the FESEM (Figure 4).

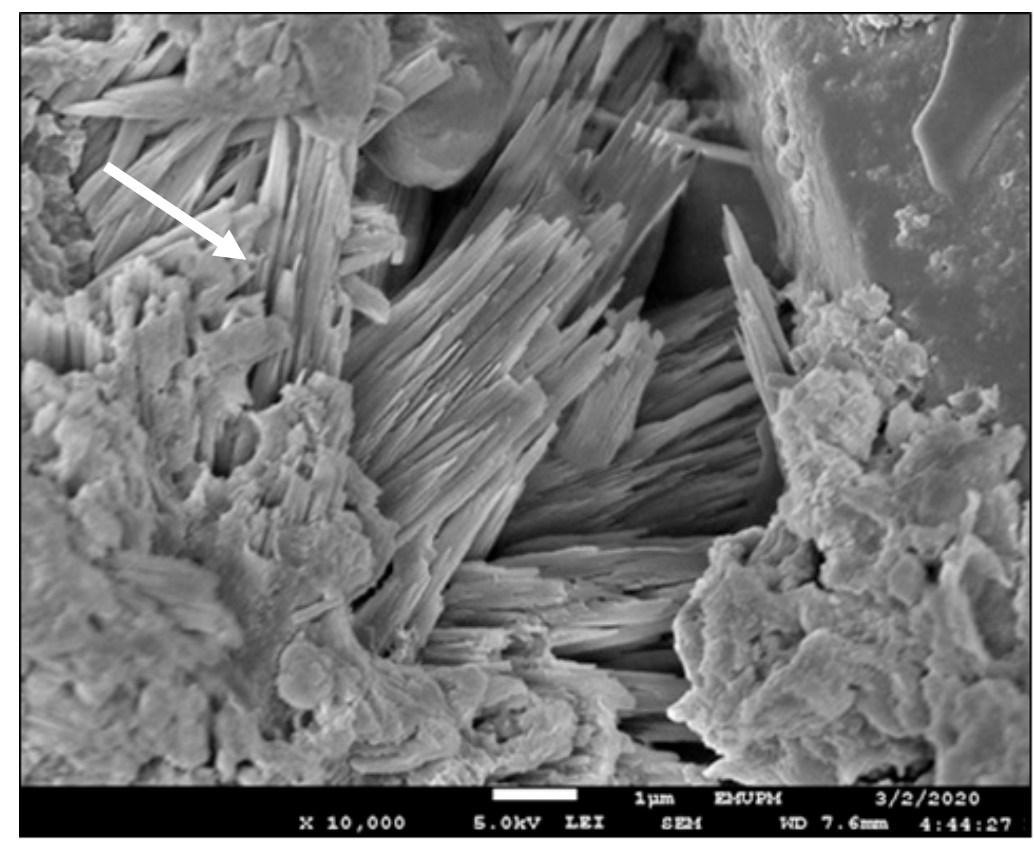

Figure 4. Acicular-shape mineral in MRSG observed under the FESEM (The needle-like structure indicated by the arrow shows the presence of gypsum in the material).

Analyses of EDX (average chemical composition of the MRSG at any particular spot e.g., at spectrum 1, 2 and 3 in the FESEM micrograph) show the co-occurrence of high levels of C (8.9\%), O (69.2) Ca (9.23) and Mg (9.1\%), non-negligible level of S (6\%), Si (1.0\%), $\mathrm{Na}(0.59 \%)$ and trace amount of $\mathrm{Ce}$ and $\mathrm{La}$, in a heterogeneous mass of crystalline materials of micrometric size (Figure 5). The chemical composition of the MRSG determined using FESEM-EDX (Figure 3) were the relative measurement, normalized to $100 \%$ and were not the absolute amount as determined by ICP-OES. 


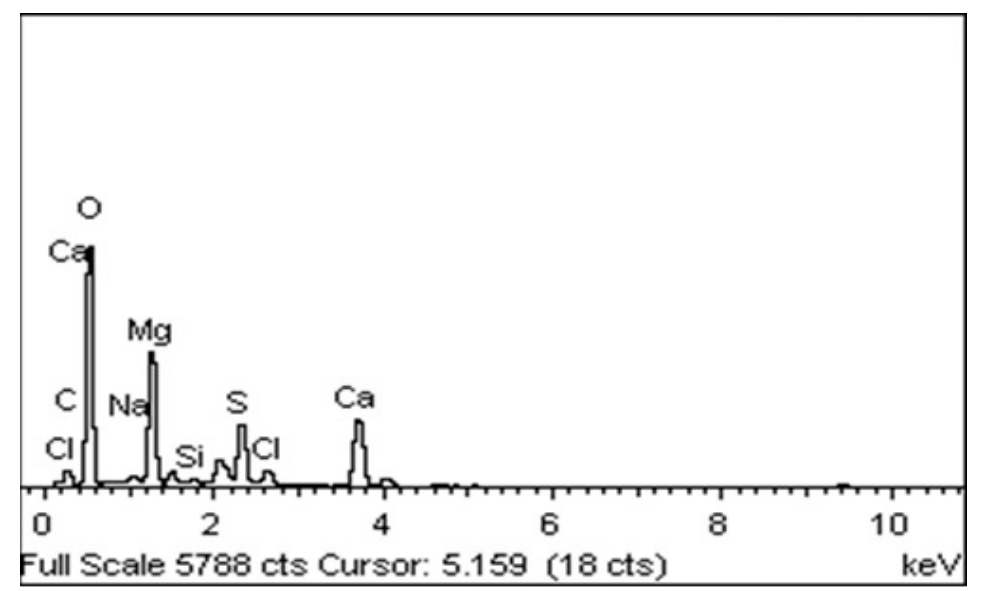

Figure 5. An elemental map showing relevant elements in the MRSG (Scale bar: $20 \mu \mathrm{m})$. The EDX spectrum shows the co-occurrence of $\mathrm{Ca}, \mathrm{O}, \mathrm{Mg}$ and $\mathrm{S}$ (wt $\%$ :). $\mathrm{Ca}=8.9 \% ; \mathrm{O}=69.2 ; \mathrm{Ca}=9.23 ; \mathrm{Mg}=9.1 \%$ ).

\subsection{Thermal Analysis}

The TG and DTA curves of MRSG is presented in Figure 6. As observed from the TG plot, weight loss occurred in three positions. The differential thermograms of the MRSG show two relatively significant endothermic effects in close sequence below $400{ }^{\circ} \mathrm{C}$. These two effects represent the two-step decomposition of the dihydrate to hemihydrate and to soluble anhydrite (Equations (1) and (2)) [46].

$$
\begin{gathered}
\mathrm{CaSO}_{4} \cdot 2 \mathrm{H}_{2} \mathrm{O}=\mathrm{CaSO}_{4} \cdot 1 / 2 \mathrm{H}_{2} \mathrm{O}+3 / 2 \mathrm{H}_{2} \mathrm{O} \\
\mathrm{CaSO}_{4} \cdot \frac{1}{2} \mathrm{H}_{2} \mathrm{O}=\mathrm{CaSO}_{4}+1 / 2 \mathrm{H}_{2} \mathrm{O}
\end{gathered}
$$

The first loss observed in the TG (15\%weight loss) was due to the evaporation of adsorbed moisture which occurred at $147.48^{\circ} \mathrm{C}$. The water loss continued until temperature reached up to $190^{\circ} \mathrm{C}$. The second endothermic area observed at $354.48^{\circ} \mathrm{C}$, which corresponds to $5.85 \%$ weight loss, was due to the loss of structural $\mathrm{H}_{2} \mathrm{O}$ from hydrated carbonates [42]. It may also be indicative of the crystalline transition of anhydrous (anhydrite III-anhydrate II) form of the gypsum [47]. This can also be attributed to the partial dehydration of silicates [48,49]. The small endothermic peak which occurred between $658.64{ }^{\circ} \mathrm{C}$ (1.69\%, weight loss), indicate the dehydration of iron and magnesium hydroxides [50].

\subsection{Environmental Impact Assessment of MRSG Application}

The detailed report on the impact of $\mathrm{Mg}$ rich synthetic application on the environment and palm oil quality has been published by Sahibin et al. [10], while detailed report on the utilization of this by-product as fertilizer has been reported by Ayanda et al. [9]. Physical and chemical characterization of a material gives conclusive evidence nature of a material and on the possible environmental impact of the material when it is land applied. Elemental chemical analysis of heavy metals content in MRSG was conducted to assess the environmental degradation that may occur following its application. For a long time, the concentrations of heavy metals and pollutants in samples of industrial byproducts such as those used in agriculture have been evaluated and this is mainly due to concern that these industrial residues can be a potential source of contaminant to water, soil, and air with grave negative impact on the environment as well as human [51,52]. 


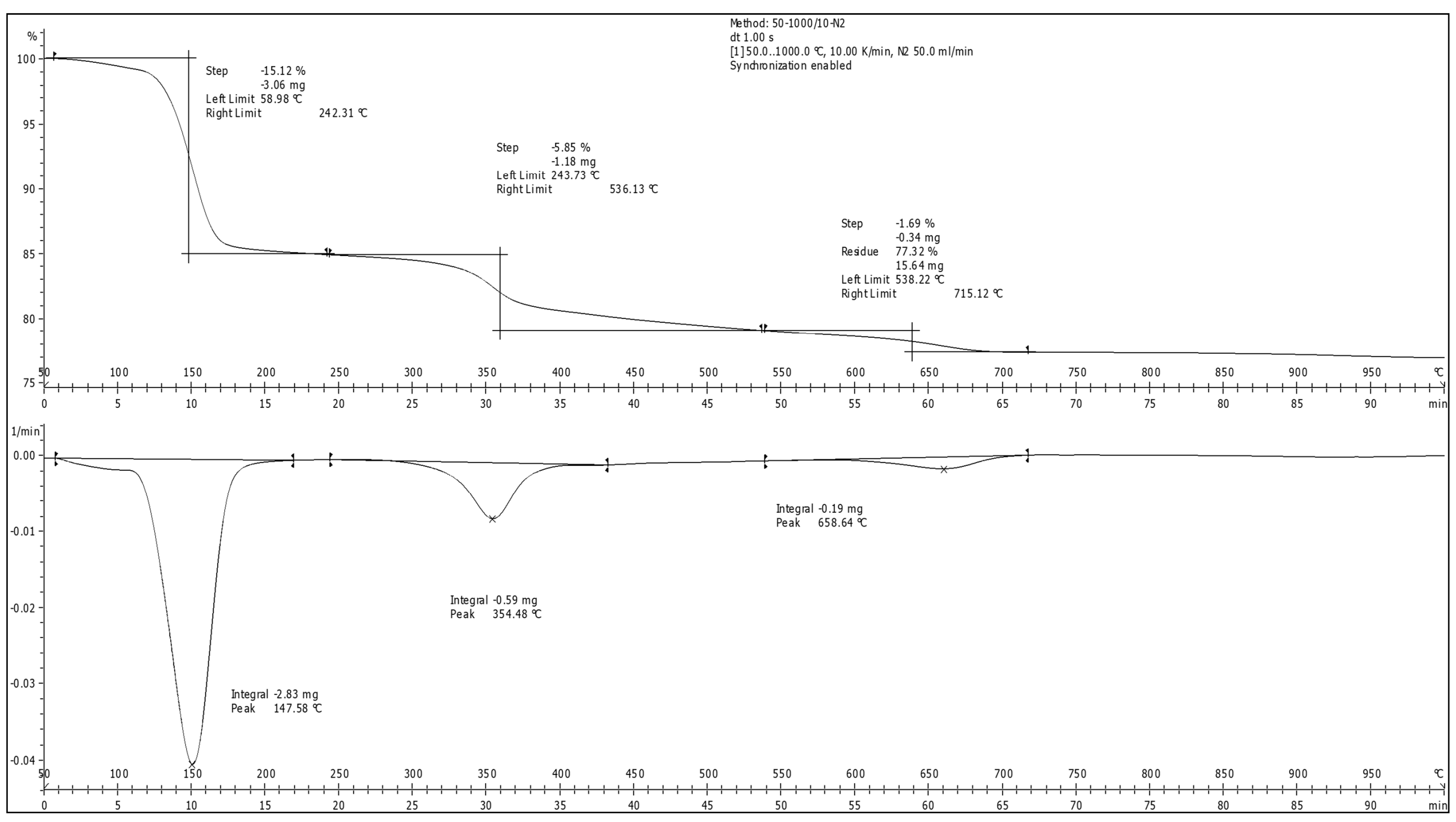

Figure 6. The thermogravimetric spectrum of MRSG. 
Heavy metals such as cadmium, copper, nickel, lead, zinc, selenium, strontium, cerium and chromium found in industrial by-products such as MRSG are considered potentially toxic elements (PTEs), and through their use, heavy metals enter the soil, despite that some of these elements are essential micronutrient required for crop productivity. The determination of soil quality following MRSG application was conducted in a previous study [3] using various measuring criteria. The indices used in the assessment include Biological Accumulation Coefficient (BAC), Geological Index (I-geo), Contamination Factor (CF) and Pollution Load Index (PLi). The result of the assessment indicated that the BAC was low to moderate for As, $\mathrm{Cd}$ and Se, while intensive BAC was recorded for $\mathrm{Zn} \mathrm{[10].}$ However, level of BAC for Zn is unlikely to result from MRSG application due to the low level of Zn contained in the MRSG used in the trial [10]. Heavy metals and PTEs in the soil under investigation and surface water in the trial and surrounding areas were determined. The effect of MRSG application on the surrounding environment during the period of the field trial was assessed using the data obtained. The heavy metals content of the treated soils was lower than their respective reference. It was found that there was no indication of the increase of heavy metals pollution in the soils treated with MRSG.

Further results of the evaluation gave indication that PTEs in the soils sampled from the plots treated with MRSG were below the investigative limit for soil reported by Zarcinas et al. [53] or in the Eco-SSL of USEPA [54]. Values of PTEs of concern in the surface water before and after MRSG application were found to be below the standard limits of the Ministry of Health Malaysia. Note that the standards for drinking water in Malaysia was adopted from the standards of the World Health Organizations. Hence, environmental risk analysis assessment showed clearly that the soil was not contaminated, indicated by the low contamination factor and pollution load index. It means that MRSG is safe for application on agricultural land in Malaysia. The result shows that heavy metals and PTEs content of the tested plots in the study area were unaffected by the application of MRSG, kieserite and GML. There were no significant differences in mean values of the treatments, showing that MRSG and kieserite treatment produced comparable or similar results. This shows that upon further test for its efficacy, MRSG can be exploited as Mgand Ca-fertilizer.

There are no global reports on the critical concentration of La and Ce in soils, however, there are reports on the mean concentration of these elements in soils of Japan and China. The respective concentration of these elements was 18 and $40 \mathrm{mg} \mathrm{kg}^{-1}$ in soils of Japan, while that of Chinese soils was 44 and $86 \mathrm{mg} \mathrm{kg}^{-1}$. It is believed that their concentration in the soil under study due to MRSG application would not exceed the amount present in the soils of Japan or China. Meanwhile, there is a dearth of information in terms of critical level of $\mathrm{Sr}$ in soils, no credible information is available in the literature. The ultimate measure for assessing the impact of MRSG application on the soil cropped to oil palm is the oil quality of fruitlets. Palm oil quality was determined on oil palm fruitlets at two years after MRSG was first applied to ensure the credibility of the results. The oil was analyzed for the presence of the common heavy metals ( $\mathrm{As}, \mathrm{Cd}, \mathrm{Pb}, \mathrm{Zn}, \mathrm{Mn}, \mathrm{Ni}, \mathrm{Cu}$ and $\mathrm{Fe}$ ) as well as the other metals of concern ( $\mathrm{Th}, \mathrm{Cr}$ and $\mathrm{Hg}$ ). The latter could be harmful for human consumption if present above the critical level. The concentration of the elements in the palm oil of the study was compared against edible oils available in the market. The results of the comparison showed there was no sign of the accumulation of heavy metals and PTEs in the oil of palms treated with MRSG. In the extracted oil, it was found that the heavy metals were much lower than those found and/or reported in other studies. Similar values were recorded in quality of oil from the soil treated with MRSG and those treated with kieserite.

\section{Conclusions}

The result of several analysis on the physico-chemical characteristics of magnesiumrich synthetic gypsum shows the nature of the material as having properties which can promote alternative use of this industrial by-product. Findings from this study show that 
MRSG properties such as the content of calcium and magnesium alongside other elements that are beneficial in the crop system indicate that this material will be useful in promoting agricultural sustainability by ameliorating deficiency conditions associated with cropping on toxic aluminum-rich and nutrient-deficient acid soil. The study showed that MRSG with a pH of 9.17 contains high amount of $\mathrm{Ca}\left(17,000 \mathrm{mg} \mathrm{kg}^{-1}\right)$ and $\mathrm{Mg}\left(15,000 \mathrm{mg} \mathrm{kg}^{-1}\right)$. These chemical compositions suggest that its application on agricultural land could increase soil $\mathrm{pH}$. The upland soils in Peninsular Malaysia are mostly classified as Ultisols and Oxisols, which are suitable for crops cultivation with proper agronomic management. The soils are acidic with high aluminum/iron concentration in the soil solution, but low in exchangeable $\mathrm{Ca}$ and $\mathrm{Mg}$. Therefore, the fertility of the soils is low; the soils do not have a sufficient amount of $\mathrm{Ca}$ and $\mathrm{Mg}$, which are essential for growth of crops.

The use of ground magnesium limestone (GML) is one of the normal practices to alleviate the aluminum toxicity and supply $\mathrm{Ca}$ and $\mathrm{Mg}$ for sustaining crop production. As MRSG contains high $\mathrm{Ca}$ and $\mathrm{Mg}$, its application can show similar effect as GML, by reducing the aluminum content in soil solution hence increasing the soil $\mathrm{pH}$. In addition, the $\mathrm{Mg}$ contained in the MRSG can be important for Mg fertilization of oil palm which occupies a large hectarage of Oxisols and Ultisols in the country. The content of rare earth elements in the material (Table 2) necessitates that land application of MRSG should be carried out with great care following extensive environmental impact assessment/studies due to several reports on potential toxic elements contamination of soils and the resulting effect on living organisms. According to health organizations such as WHO, approximately 12.6 million deaths have been recorded globally from $>100$ diseases resulting from contaminated environments such as polluted soils and water. In light of this, regulations, environmental policies, and standards for water and soil pollution prevention and control with strict restrictions on the usage of this industrial residue on farmland should be proposed prior to large scale adoption of MRSG.

The projected utilization of this by-product may also be a furtherance of the United Nations Millennium Development Goals (MDGs) which seeks to promote environmental sustainability. This is achieved by limiting the exploitation of nonrenewable minerals, i.e., mined gypsum (used as acid soil ameliorant) and kieserite (used as Mg fertilizer), which this material may be able to replace as an alternative while also promoting efficient disposal of the material. These objectives are also in line with the Eleventh Malaysia Plan 2016-2020 initiative, which looks at managing chemical plant wastes holistically. The initiative states that using wastes as a resource gives an economic value, hence diverting it away from landfill towards more productive use. This is especially interesting and worthy of exploring; however, additional studies and long-term trials should be conducted in several locations to prove beyond doubt that utilization of this material will not lead to a significant environmental impact. It is worthy to note that sustainability of the environment and quality of human life is of utmost importance compared to any benefit to be derived from land application of this or other industrial by-products.

Author Contributions: Conceptualization, methodology, analysis, writing-original draft preparation, F.A.A., S.J., M.F.M.A., S.Z. All authors have read and agreed to the published version of the manuscript.

Funding: This research was funded by the Research Management Center (RMC), Universiti Putra Malaysia with research grant number (GP-IPS/2019/9680300).

Institutional Review Board Statement: Not applicable.

Informed Consent Statement: Not applicable.

Data Availability Statement: The data presented in this study are available in the article.

Acknowledgments: The authors wish to acknowledge the support of Lynas Sdn. Bhd. For providing the necessary materials for this research.

Conflicts of Interest: The authors wish to state that there is no conflict of interest whatsoever. 


\section{References}

1. Evans, C.H. Biochemistry of the Lanthanides; Springer Science and Business Media: Berlin, Germany, 2013.

2. Henderson, P. Rare earth element geochemistry. Developments in Geochemistry; Elsevier: Amsterdam, The Netherlands, 1984 ; Volume 2.

3. Wen, B.; Liu, Y.; Hu, X.Y.; Shan, X.Q. Effect of earthworms (Eisenia fetida) on the fractionation and bioavailability of rare earth elements in nine Chinese soils. Chemosphere 2006, 63, 1179-1186. [CrossRef]

4. Tyler, G. Rare earth elements in soil and plant systems-A review. Plant Soil 2004, 267, 191-206. [CrossRef]

5. Aguar, P. Report on Trans-Atlantic Workshop on Rare Earth Elements and Other Critical Materials for a Clean Energy Future; European Union: Brussels, Belgium, 2011.

6. Brioschi, L.; Steinmann, M.; Lucot, E.; Pierret, M.C.; Stille, P.; Prunier, J.; Badot, P.M. Transfer of rare earth elements (REE) from natural soil to plant systems: Implications for the environmental availability of anthropogenic REE. Plant Soil 2013, 366, 143-163. [CrossRef]

7. Lynas. Available online: https://www.lynascorp.com/sustainability/residue-tailings-management (accessed on 12 June 2020).

8. Goonan, T.G. Rare Earth Elements: End Use and Recyclability; US Department of the Interior, US Geological Survey: Reston, VA, USA, 2011.

9. Ayanda, A.F.; Shamshuddin, J.; Fauziah, C.I.; Radziah, O. Utilization of magnesium-rich synthetic gypsum as magnesium fertilizer for oil palm grown on acidic soil. PLOS ONE 2020, 16, 15. [CrossRef]

10. Sahibin, A.R.; Shamshuddin, J.; Fauziah, C.I.; Radziah, O.; Razi, I.W.; Enio, M.S. Impact of Mg rich synthetic gypsum application on the environment and palm oil quality. Sci. Total Environ. 2019, 652, 573-582. [CrossRef] [PubMed]

11. Garrido, F.; Illera, V.; Vizcayno, C.; García-González, M.T. Evaluation of industrial by-products as soil acidity amendments: Chemical and mineralogical implications. Eur. J. Soil Sci. 2003, 54, 411-422. [CrossRef]

12. Anawar, H.M.; Akter, F.; Solaiman, Z.M.; Strezov, V. Biochar: An emerging panacea for remediation of soil contaminants from mining, industry and sewage wastes. Pedosphere 2015, 25, 654-665. [CrossRef]

13. Lee, X.J.; Lee, L.Y.; Gan, S.; Thangalazhy-Gopakumar, S.; Ng, H.K. Biochar potential evaluation of palm oil wastes through slow pyrolysis: Thermochemical characterization and pyrolytic kinetic studies. Bioresour. Technol. 2017, 236, 155-163. [CrossRef] [PubMed]

14. Tang, L.; Yu, J.; Pang, Y.; Zeng, G.; Deng, Y.; Wang, J.; Ren, X.; Ye, S.; Peng, B.; Feng, H. Sustainable efficient adsorbent: Alkali-acid modified magnetic biochar derived from sewage sludge for aqueous organic contaminant removal. Chem. Eng. J. 2018, 336, 160-169. [CrossRef]

15. Kuan, S.H.; Saw, L.H.; Ghorbani, Y. A review of rare earths processing in Malaysia. In Proceedings of the Inemeritus Prof. Dr. Faizah Binti Mohd Sharoum Chairman UMT International Annual Symposium on Sustainability Science and ManagementUMTAS, Kuala Terengganu, Malaysia, 9-11 July 2016; Volume 42, p. 105.

16. US EPA. Method 3050B: Acid Digestion of Sediments, Sludges, and Soils, in: Selected Analytical Methods for Environmental Remediation and Recovery (SAM). 2018. Available online: https:/ / www.epa.gov/homeland-security-research/epa-method-30 50b-acid-digestion-sediments-sludges-and-soils (accessed on 5 February 2020).

17. Boumans, P.W.J.M. Inductively Coupled Plasma Emission Spectroscopy, Part 1: Methodology, Instrumentation and Performance; WileyInterscience: Hoboken, NJ, USA, 1987.

18. Navarro, C.; Díaz, M.; Villa-García, M.A. Physico-chemical characterization of steel slag. Study of its behavior under simulated environmental conditions. Environ. Sci. Technol. 2010, 44, 5383-5388. [CrossRef] [PubMed]

19. Hsu, J.H.; Lo, S.L. Chemical and spectroscopic analysis of organic matter transformations during composting of pig manure. Environ. Pollut. 1999, 104, 189-196. [CrossRef]

20. Fauziah, C.I. Solid Waste Management: An Inaugural Lecture; Universiti Putra Malaysia Press: Serdang, Malaysia, 2019.

21. Li, J.Y.; Liu, Z.D.; Zhao, W.Z.; Masud, M.M.; Xu, R.K. Alkaline slag is more effective than phosphogypsum in the amelioration of subsoil acidity in an Ultisol profile. Soil Till. Res. 2015, 149, 21-32. [CrossRef]

22. Valle, L.A.; Rodrigues, S.L.; Ramos, S.J.; Pereira, H.S.; Amaral, D.C.; Siqueira, J.O.; Guilherme, L.R. Beneficial use of a by-product from the phosphate fertilizer industry in tropical soils: Effects on soil properties and maize and soybean growth. J. Clean. Prod. 2016, 112, 113-120. [CrossRef]

23. Shamshuddin, J.; Ismail, H. Reactions of ground magnesium limestone and gypsum in soils with variable-charge minerals. Soil Sci. Soc. Am. J. 1995, 59, 6-12. [CrossRef]

24. Shamshuddin, J.; Daud, W.N.; Ismail, R.; Ishak, C.F.; Panhwar, Q.A. Ultisols \& Oxisols: Enchancing Their Productivity for Oil Palm, Rubber and Cocoa Cultivation; Universiti Putra Malaysia Press: Serdang, Malaysia, 2015.

25. Daud, W.N. Rubber Plantation: Soil Management \& Nutritional Requirement; Universiti Putra Malaysia Press: Serdang, Malaysia, 2013.

26. Alloway, B.J. Sources of heavy metals and metalloids in soils. In Heavy Metals in Soils; Springer: Dordrecht, Germany, 2013; pp. 11-50.

27. Yang, Q.; Li, Z.; Lu, X.; Duan, Q.; Huang, L.; Bi, J. A review of soil heavy metal pollution from industrial and agricultural regions in China: Pollution and risk assessment. Sci. Total Environ. 2018, 642, 690-700. [CrossRef] [PubMed]

28. Sari, N.A.; Fauziah, C.I.; Rosenani, A.B. Characterization of oil palm empty fruit bunch and rice husk biochars and their potential to adsorb arsenic and cadmium. Am. J. Agric. Biol. Sci. 2014, 9, 450-456. [CrossRef]

29. Samsuri, A.W.; Sadegh-Zadeh, F.; She-Bardan, B.J. Adsorption of As(III) and As(V) by Fe coated biochars and biochars produced from empty fruit bunch and rice husk. J. Environ. Chem. Eng. 2013, 1, 981-988. [CrossRef] 
30. Fauziah, C.I.; Nur Hanani, M.; Zauyah, S.; Samsuri, A.W.; Rosazlin, A. Co-application of red gypsum and sewage sludge on acidic tropical soils. Comm. Soil Sci. Plan. 2011, 42, 2561-2571. [CrossRef]

31. Nur Hanani, M.; Fauziah, C.I.; Samsuri, A.W.; Zauyah, S. Utilization of drinking-water treatment residue to immobilize copper and zinc in sewage-sludge-amended soils. Land Contam. Reclamat. 2008, 16, 319-332. [CrossRef]

32. Lua, A.C.; Yang, T.; Guo, J. Effects of pyrolysis conditions on the properties of activated carbons prepared from pistachio-nut shells. J. Anal. Appl. Pyrolysis 2004, 72, 279-287. [CrossRef]

33. Lou, W.; Guan, B.; Wu, Z. Dehydration behavior of FGD gypsum by simultaneous TG and DSC analysis. J. Therm. Anal. Calorim. 2011, 104, 661-669. [CrossRef]

34. Caillahua, M.C.; Moura, F.J. Technical feasibility for use of FGD gypsum as an additive setting time retarder for Portland cement. J. Mater. Res. Technol. 2018, 7, 190-197. [CrossRef]

35. Li, J.; Verweij, R.A.; van Gestel, C.A. Lanthanum toxicity to five different species of soil invertebrates in relation to availability in soil. Chemosphere 2018, 193, 412-420. [CrossRef]

36. Larsson, M.A.; Baken, S.; Gustafsson, J.P.; Hadialhejazi, G.; Smolders, E. Vanadium bioavailability and toxicity to soil microorganisms and plants. Environ. Toxicol. Chem. 2013, 32, 2266-2273. [CrossRef] [PubMed]

37. Liang, C.N.; Tabatabai, M.A. Effects of trace elements on nitrification in soils. J. Environ. Qual. 1978, 7, 293. [CrossRef]

38. Gupta, D.K.; Deb, U.; Walther, C.; Chatterjee, S. Strontium in the ecosystem: Transfer in plants via root system. In Behaviour of Strontium in Plants and the Environment; Springer: Cham, Switzerland, 2018.

39. Li, J.Y.; Wang, N.; Xu, R.K.; Tiwari, D. Potential of industrial byproducts in ameliorating acidity and aluminum toxicity of soils under tea plantation. Pedosphere 2010, 20, 645-654. [CrossRef]

40. Queralt, I.; Juliá, R.; Plana, F.; Bischoff, J.L. A hydrous Ca-bearing magnesium carbonate from playa lake sediments, Salines Lake, Spain. Am. Mineral. 1997, 82, 812-819. [CrossRef]

41. Mayo, D.W.; Foil, A.M.; Hannah, R.W. Course Notes on the Interpretation of Infrared and Raman Spectra; Wiley-Interscience: New York, NY, USA, 2004; pp. 316-318.

42. Van der Marel, H.W.; Beutelspacher, H. Atlas of Infrared Spectroscopy of Clay Minerals and Their Admixtures; Elsevier: Amsterdam, The Netherlands, 1976; pp. 224-229.

43. Namduri, H.; Nasrazadani, S. Quantative analysis of iron oxides using Fourier transform infrared spectrophotometry. Corros. Sci. 2008, 50, 2493-2497. [CrossRef]

44. Hirsch, J.; Lowry, S.R.; Dowd, M. X-ray fluorescence and FT-IR identification of strontium and carbonate in domestic and imported gypsum drywall. Spectroscopy 2010, 25, 30.

45. Chernysh, Y.; Balintova, M.; Plyatsuk, L.; Holub, M.; Demcak, S. The influence of phosphogypsum addition on phosphorus release in biochemical treatment of sewage sludge. Int. J. Environ. Res. Public Health 2018, 15, 1269. [CrossRef] [PubMed]

46. Ghazi, W.K.; Hugi, E.; Wullschleger, L.; Frank, T.H. Gypsum board in fire-modeling and experimental validation. J. Fire Sci. 2007, 25, 267-282. [CrossRef]

47. Wang, S.D.; Scrivener, K.L. Hydration products of alkali activated slag cement. Cem. Concr. Res. 1995, 25, 561-571. [CrossRef]

48. Waligora, J.; Bulteel, D.; Degrugilliers, P.; Damidot, D.; Potdevin, J.L.; Measson, M. Chemical and mineralogical characterizations of LD converter steel slags: A multi-analytical techniques approach. Mater. Charact. 2010, 61, 39-48. [CrossRef]

49. Masaguer, V.; Oulego, P.; Collado, S.; Villa-García, M.A.; Díaz, M. Characterization of sinter flue dust to enhance alternative recycling and environmental impact at disposal. J. Waste Manag. 2018, 79, 251-259. [CrossRef]

50. Setién, J.; Hernández, D.; González, J.J. Characterization of ladle furnace basic slag for use as a construction material. Constr. Build. Mater. 2009, 23, 1788-1794. [CrossRef]

51. Khalid, S.; Shahid, M.; Bibi, I.; Sarwar, T.; Shah, A.H.; Niazi, N.K. A review of environmental contamination and health risk assessment of wastewater use for crop irrigation with a focus on low and high-income countries. Int. J. Environ. Res. Public Health 2018, 15, 895. [CrossRef]

52. Turan, V.; Khan, S.A.; Iqbal, M.; Ramzani, P.M.; Fatima, M. Promoting the productivity and quality of brinjal aligned with heavy metals immobilization in a wastewater irrigated heavy metal polluted soil with biochar and chitosan. Ecotoxicol. Environ. Saf. 2018, 161, 409-519. [CrossRef] [PubMed]

53. Zarcinas, B.A.; Ishak, C.F.; McLaughlin, M.J.; Cozens, G. Heavy metals in soils and crops in Southeast Asia. Environ. Geochem. Health 2004, 26, 343-357. [CrossRef]

54. US EPA. Guidance for Developing Ecological Soil Screening Levels. 2007. Available online: https://www.epa.gov/sites/ production/files/201509/documents/ecossl_guidance_chapters.pdf (accessed on 5 February 2018). 